\title{
Friendship Among Roommates - First Year Students' Experience in a Malaysia Public University
}

\author{
Azian binti Abd Aziz @ Ahmad ${ }^{1 *}$, Norhanim binti Abdul Samat ${ }^{2}$, Muhammad Akmal \\ bin Ayob $^{3}$, Syahrul Azwan bin Shaedid ${ }^{4}$ \\ ${ }^{1}$ Language Academy, Universiti Teknologi Malaysia, 81300 Johor Bahru, Malaysia \\ ${ }^{2}$ Language Academy, Universiti Teknologi Malaysia, 81300 Johor Bahru, Malaysia \\ ${ }^{3}$ Institute of Human Centered Engineering (iHumEn), Universiti Teknologi Malaysia, 81300 Johor Bahru, Malaysia \\ ${ }^{4}$ Faculty of Engineering, Universiti Teknologi Malaysia, 81300 Johor Bahru, Malaysia
}

*Corresponding author.Email: azian@utm.my

\begin{abstract}
This paper studies the role of college roommate relationships in students' college adjustment during their first year study in a selected university campus. It used questionnaire to collect data from 105 respondents in a public university. Results suggest there are differences between male and female students' experiences in developing relationships with their roommates. The findings revealed that adaptation process is necessary in order to assist the students in coping with the new environment.
\end{abstract}

Keywords: Relationships, Adolescents, First-Year Experience, Self-Development, Campus, Roommates

\section{INTRODUCTION}

Friends are people who are connected to each other at an emotional level (Dunbar, 2018) [1] developing bonding (Korchmaros \& Kenny, 2006) [2] and offering psychological, social and even economic support (Sutcliffe, et al., 2012) [3]. Fostering friendships during late adolescence, namely at the age of 18 and 20, have been identified to be important in self-development (Viner et al., 2012) [4]. This is because late adolescence is a significant period for youths in forming identity, relationships and future career paths (Young, Marshall \& Murray, 2016) [5].

The start of university life offers youths in late adolescence the opportunity to form new friendships, particularly with their respective roommates. First year students are typically faced with a situation that requires them to be roommates with a person they do not know. This in fact could be a starting point for first year students to form new social networks (Markey \& Kurtz, 2006) [6]. Roommate relationships have been found to influence first year students' campus experience (Zimmerman, 2003) [7] as roommates can offer peer support that has been known to play a role in physical appearance (Jones, Vigfusdottir \& Lee, 2004) [8] and academic achievement (Lessard \& Juvonen, 2018) [9], among others.

However, assigning two complete strangers as roommates could lead to a number of possibilities. On the one hand, being closely confined together as roommates may actually lead to a positive relationship and actual friendship. On the other hand, being randomly assigned to a person who is not compatible with oneself could lead to dissatisfaction and stress. Or, it could also lead to indifference. As friendship may affect students wellbeing and academic achievement, particularly when acclimatizing to a new academic environment (Lessard \& Juvonen, 2018) ment (Lessard \& Juvonen, 2018) [10], this paper thus aimed at examining the level of friendship between roommates among first year students of a public university in Malaysia. It also investigated whether there is a difference in the level of friendship formed between same gender roommates. 


\subsection{Related Work}

\subsubsection{First Year Student Transition}

Leaving home for the purpose of pursuing higher education is a major transition for most adolescents. College life offers adolescents the opportunity to grow and develop autonomy and individual identity (Arnett, 2000) [11]. However, for many first year tertiary education students, this would be the first time they would be away from home. This could lead to feelings of displacement and stress. McInnis et al. (2000) [12] found the greatest rate of student dropping out of college occurred among first year undergraduate students.

In managing such feelings, residential colleges need to commit to the following: i) student welfare, ii) student education, and iii) student social communities (Braxton et al., 1995) [13]. In other words, colleges and universities should not only focus on academic matters, but should also promote social integration among peers. Establishing social networks and friendships is clearly important in first year student transition.

\subsubsection{Significance of Friendship during Adolescence}

Having friends allows the sharing of experiences and feelings, while those without friends tend to be socially isolated (Tome et al., 2012) [14]. Friendships are thus positively correlated to psychological well-being (Ueno, 2004) [15]. Friendships among adolescents have in fact been found to be both influential and important. Brown and Larson (2009) [16] suggest that peers play a significant role in influencing adolescents' activities, attitude and emotional well-being. Adolescents with good peer support have reported a high sense of belonging in school, leading to positive academic achievements (Vaquera \& Kao, 2008) [17].

Academic settings, be it schools, colleges or universities, provide adolescents with a social for personal and social development (Ruini et al., 2009) [18]. Such environments offer the opportunity for different peer communities to thrive, promoting social interactions and self-esteem. This suggests that peer relationships during adolescents are particularly are important for social as well as emotional adjustments.

\subsubsection{Importance of Students' Roommate Relationships}

Peer relationships may affect students' sense of belonging and affiliation with their respective universities (Strayhorn, 2012) [19]. Since college or university students spend a substantial amount of time in residential halls, these on campus residences are epicenters for student engagement (Pascarella \& Terenzini, 2005) [20] and learning (Blimling, 2010) [21]. On campus residences thus are settings that may support students' development both at the academic and social levels.

Accommodation in college residential halls tends to require students to not only share general facilities, but also to share living spaces. Thus, college roommate relationships are unique as the living conditions require roommates to make compromises in terms of noise level, waking and sleeping hours and cleanliness, to name a few. For first year students, this could be a daunting experience as they do not get to choose their roommates. Rather, roommates tend to be assigned on a random basis. Studies on roommate relationships in the west suggest that there is widespread roommate conflict among college students. For instance, $50.1 \%$ female students and $44.1 \%$ male students reported experiencing conflicts of some form with their respective roommates (Liu, Sharkness, \& Pryor, 2008) [22]. Additionally, 5.6\% undergraduates reported that not getting along with their roommates affected their academic performance such as achieving lower grades or even dropping out of a programme (American College Health Association, 2012) [23]. To mitigate roommate issues, it is important for roommates to engage in positive interactions. Intimacy-building behaviours such as smiling and eye-contact have been found to foster roommate relations, while distancing behaviours like physical distance and fidgeting tend to lead to negative roommate relations (Trail \& West, 2009) [24]. In another study, it was shown that roommates with more common similarities tend to from stronger friendships, while those with less common interests tend to display a decline in friendship over time (West et al., 2009) [25].

Despite the importance of roommate relationships, hardly any studies have looked at the issue in the context of Asia in general and Malaysia in particular. This study thus investigated roommate relationships experienced by first year female and male students at a public university in Malaysia. This study aimed at assessing feelings of friendship between roommates, emotions experienced towards their roommates, and behaviours of roommates that contribute towards intimacy-building and intimacydistancing relations. 


\section{METHODOLOGY}

The participants were first year, second semester students from the Faculty of Biomedical Engineering, Architecture and Built Environment and Mechanical Engineering chosen at random. All participants had same gender first year students who were randomly assigned as their respective roommates when they were provided oncampus accommodation in the first semester of their studies. In other words, at the time of data collection period, the participants would have been roommates with someone whom they do not know for approximately 18 weeks. The participants were given the questionnaires during one of the activities organised by the residential college.

The participants were asked to complete a self-report questionnaire that was constructed based on the review of literature on roommate relations and friendships (Trail \& West, 2009; West et al., 2009). The questionnaire contained 43 closed question items, aimed at assessing participants' satisfaction with their roommates, intimacybuilding and intimacy-distancing building practised by their roommates, as well as their feelings of anxiety, friendship and mutual respect towards their roommates.

Table 1 shows an overview of the question items in the questionnaire.

Table 1 Overview of Roommate Relations Question Items

\begin{tabular}{|l|c|l|}
\hline $\begin{array}{l}\text { Question } \\
\text { Item }\end{array}$ & Quantity & Focus Area \\
\hline Q 1 - 4 & 4 & $\begin{array}{l}\text { Satisfaction with } \\
\text { roommate }\end{array}$ \\
\hline Q 5.1-5.5 & 5 & $\begin{array}{l}\text { Intimacy-building } \\
\text { behaviours }\end{array}$ \\
\hline Q 5.6-5.10 & 5 & $\begin{array}{l}\text { Intimacy-distancing } \\
\text { behaviours }\end{array}$ \\
\hline Q 6.1-6.8 & 8 & Feelings of anxiety \\
\hline Q 6.9-6.18 & 10 & Feelings of friendship \\
\hline Q 7 -11 & 11 & Mutual respect \\
\hline
\end{tabular}

All question items were formulated as a 5-point likert scale item. Question items from 1 to 5.10 required students to select 'strongly disagree, disagree, not sure, agree, or strongly agree', while questions items from 6.1 to 11 required participants to select 'never, rarely, not sure, frequently, very frequently.' Data obtained from the questionnaire were analysed statistically using SPSS version 22.

\section{FINDINGS AND DISCUSSION}

In exploring the results, the data were assessed for the respective relationships for male-male and femalefemale roommates. Table 2 shows the satisfaction level of participants with same gender roommates.

Table 2 Satisfaction Level with Roommates

\begin{tabular}{|c|c|c|}
\hline & \multicolumn{2}{|c|}{ Mean Value } \\
\hline & Male & Female \\
\hline $\begin{array}{l}\text { My roommate and I are becoming } \\
\text { close friends }\end{array}$ & 4.8 & 4.1 \\
\hline $\begin{array}{l}\text { I am completely myself when I am } \\
\text { around my roommate }\end{array}$ & 4.6 & 3.8 \\
\hline $\begin{array}{l}\text { It is easy to express who I really am } \\
\text { when I am with my roommate }\end{array}$ & 4.3 & 4.0 \\
\hline $\begin{array}{l}\text { If I had to decide today, I would live } \\
\text { with my roommate again next year }\end{array}$ & 4.4 & 3.8 \\
\hline Average Mean Value & 4.53 & 3.93 \\
\hline
\end{tabular}

* Based on a scale of 1 (strongly disagree) to 5 (strongly agree)

In general, male participants indicated a higher level of satisfaction with their respective roommates. Their relationship become closer due to the sharing of room together and they are truthful about their relationship about themselves. Overall, the mean value is higher at 4.53 while female score is 3.93 mean value.

Table 3 Intimacy-building Behaviours Experienced with Roommates

\begin{tabular}{|l|c|c|}
\cline { 2 - 3 } \multicolumn{1}{c|}{} & \multicolumn{2}{c|}{ Mean Value } \\
\hline When interacting with me... & Male & Female \\
\hline my roommate smiles a lot & 3.9 & 3.9 \\
\hline $\begin{array}{l}\text { my roommate participates a lot } \\
\text { during interaction }\end{array}$ & 4.0 & 4.4 \\
\hline $\begin{array}{l}\text { my roommate displays a pleasant } \\
\text { personality }\end{array}$ & 4.2 & 4.2 \\
\hline $\begin{array}{l}\text { my roommate is friendly } \\
\text { Average Mean Value }\end{array}$ & 4.5 & 4.4 \\
\hline $\begin{array}{l}\text { my roommate appears engaged and } \\
\text { interested }\end{array}$ & 4.4 & 4.2 \\
\hline \multicolumn{2}{|c|}{} & \\
\hline
\end{tabular}


The table above shows that among the behaviors that increase a roommate's intimacy are through smiling, communicating, showing a pleasant, friendly personality and also building a good relationship. It can be seen from the average value found in this study that female students have a higher intimacy value of 4.22 compared to male values of 4.20 in Table 3 .

Table 4 Intimacy-distancing Behaviours

\section{Experienced with Roommates}

\begin{tabular}{|l|c|c|}
\cline { 2 - 3 } \multicolumn{1}{c|}{} & \multicolumn{2}{c|}{ Mean Value } \\
\cline { 2 - 3 } \multicolumn{1}{c|}{ When interacting with me... } & Male & Female \\
\hline my roommate fidgets a lot & 3.2 & 2.6 \\
\hline my roommate avoids eye contact & 2.3 & 1.7 \\
\hline $\begin{array}{l}\text { my roommate conceals his/her true } \\
\text { opinions }\end{array}$ & 3.3 & 2.9 \\
\hline my roommate makes me feel small & 1.7 & 1.8 \\
\hline my roommate doesn't talk much & 2.3 & 2.1 \\
\hline Average Mean Value & 2.56 & 2.22 \\
\hline
\end{tabular}

* Based on a scale of 1 (strongly disagree) to 5 (strongly agree)

In addition to the behaviors that lead to the intimacy of a roommate, there are also some behaviors that cause the relationship or friendship of the roommate to be more relaxed. According to Table 3, the average mean value for female students is 2.22 compared to male students, with an average value of 2.56. Some of these factors are lack of communication, avoiding eye contact, concealing of actual opinions and also a feeling of inferiority. The results show that female show less intimacy distancing behavior compared to male students.

\section{Table 5 Feelings of Anxiety towards Roommates}

When in the company of my roommate I feel the following emotions

\begin{tabular}{|l|c|c|}
\cline { 2 - 3 } \multicolumn{1}{c|}{} & \multicolumn{2}{c|}{ Mean Value } \\
\cline { 2 - 3 } \multicolumn{1}{c|}{} & Male & Female \\
\hline resentful & 1.1 & 1.4 \\
\hline irritated & 1.7 & 1.5 \\
\hline disappointed & 1.4 & 1.7 \\
\hline tense & 1.4 & 1.6 \\
\hline annoyed & 1.4 & 1.7 \\
\hline
\end{tabular}

\begin{tabular}{|c|c|c|}
\hline angry & 1.2 & 1.8 \\
\hline suspicious & 1.6 & 1.9 \\
\hline defensive & 1.9 & 1.9 \\
\hline Average Mean Value & 1.46 & 1.69 \\
\hline
\end{tabular}

* Based on a scale of 1 (never) to 5 (very frequently)

This study has shown that women are negatively emotional. The study also shows that female anxiety level about a roommate is higher than that of a male student. However, we conclude that this factor is not a major factor in a roommate's relationship.

\section{Table 6 Feelings of Friendship towards Roommates}

When in the company of my roommate I feel the following emotions

\begin{tabular}{|l|c|c|}
\cline { 2 - 3 } \multicolumn{1}{c|}{} & \multicolumn{2}{c|}{ Mean Value } \\
\cline { 2 - 3 } \multicolumn{1}{c|}{} & Male & Female \\
\hline accepted & 4.2 & 3.4 \\
\hline cared for & 4 & 3.6 \\
\hline supported & 4.2 & 3.9 \\
\hline appreciated & 4.1 & 3.8 \\
\hline happy & 4.2 & 4 \\
\hline excited & 3.9 & 3.5 \\
\hline contented & 3.7 & 4.1 \\
\hline alert & 3.5 & 4 \\
\hline satisfied Average Mean Value & 3.9 & 3.9 \\
\hline enthusiastic & 4.1 & 4 \\
\hline \multicolumn{2}{|c|}{} & 3.82 \\
\hline
\end{tabular}

* Based on a scale of 1 (never) to 5 (very frequently)

In this study, among the elements mentioned are accepted, cared for, supported, appreciated, happy, excited, contented, alert, satisfied and enthusiastic. Male students in this study are found to have higher feelings of friendship than the female students with an average difference of 0.15 .

Table 7 Feelings of Mutual Respect towards Roommates

\begin{tabular}{|l|c|c|}
\cline { 2 - 3 } \multicolumn{1}{c|}{} & \multicolumn{2}{c|}{ Mean Value } \\
\cline { 2 - 3 } \multicolumn{1}{c|}{} & Male & Female \\
\hline $\begin{array}{l}\text { I listen to my roommate's } \\
\text { concerns and ideas }\end{array}$ & 4 & 3.9 \\
\hline $\begin{array}{l}\text { I'm open to my roommate's } \\
\text { different view point }\end{array}$ & 4 & 3.9 \\
\hline $\begin{array}{l}\text { I give my roommate enough space } \\
\text { to express him/herself }\end{array}$ & 4.3 & 4.1 \\
\hline I'm approachable enough to allow & 4.3 & 3.8 \\
\hline
\end{tabular}




\begin{tabular}{|l|c|c|}
\hline $\begin{array}{l}\text { my roommate to speak openly and } \\
\text { frankly to me }\end{array}$ & & \\
\hline $\begin{array}{l}\text { I'm able to explain my view } \\
\text { points in a non-threatening } \\
\text { manner }\end{array}$ & 4.2 & 4 \\
\hline Average Mean Value & 4.16 & 3.94 \\
\hline
\end{tabular}

* Based on a scale of 1 (never) to 5 (very frequently)

Mutual respect not only has a positive impact but also improves the relationship of a roommate. In this study, male and female students also showed an almost similar value in areas such as listening to a roommate expressing ideas and exchanging views on issues. Also, in respect to allowing freedom of speech, the participants allowed space for their roommates to be more open towards communication. This average has a very positive effect on male students with 4.16 mean value compared to female students with a mean value of 3.94. We can conclude that male students are more open for communication compared to the females.

\section{CONCLUSION}

Interaction between students of similar or different backgrounds in the same room in residential campus is considered as roommate relationship. For a specific period of time, normally a year or two semesters, students need to conform to the routine and behaviours of their roommates. There is strong evidence that the level of friendship between roommates among first year students is different for both genders. We identified that females are more intimate with their roommates. However, their communication is not as open as the male students. Besides this, male students are more satisfied with the roommate relationship. Furthermore, our analyses show that females show less distancing behavior but are more emotional compared to male students. Male students are not worried about their relationships with their roommates, have more positive feelings and show more mutual respect for their roommates. The findings suggest that first year students especially female students sometimes face difficulties when they are placed with someone unfamiliar to them. On the other hand, these challenges also would motivate them to develop new relationships better. The adjustment to campus life takes time and support from different people and bodies.

\section{IMPLICATIONS}

Based on the findings of this study, we put forward some recommendations for students and residential colleges in assisting first year students to develop relationships with their new roommates. Firstly, students can develop relationships by giving one another some space, which means one must be respectful of the other and keeping their areas clean and neat and respecting one another's belongings. Secondly, if problems persist, students should address the problems and work on resolving issues between them. They could seek help from the fellows' council who are trained to handle the conflicting issues. Thirdly, as roommates, they should not expect too highly of the other. Finally, the university can also adopt rooming policy that allows new students to choose their own roommates. Living together and adapting to one another could be a rewarding experience as they have to adapt to interpersonal and intercultural experiences. 


\section{REFERENCES}

[1] Dunbar, R. I. (2018). The anatomy of friendship. Trends in cognitive sciences, 22(1), 32-51.

[2] Korchmaros, J. D., \& Kenny, D. A. (2006). An evolutionary and close-relationship model of helping. Journal of social and Personal Relationships, 23(1), 21-43.

[3] Sutcliffe, A., Dunbar, R., Binder, J., \& Arrow, H. (2012). Relationships and the social brain: integrating psychological and evolutionary perspectives. British journal of psychology, 103(2), 149-168.

[4] Viner, R. M., Ozer, E. M., Denny, S., Marmot, M., Resnick, M., Fatusi, A., \& Currie, C. (2012). Adolescence and the social determinants of health. The lancet, 379(9826), 1641-1652.

[5] Young, R. A., Marshall, S. K., \& Murray, J. (2017). Prospective content in the friendship conversations of young adults. Journal of adolescence, 54, 9-17.

[6] Markey, P. M., \& Kurtz, J. E. (2006).

Increasing acquaintanceship and complementarity of behavioral styles and personality traits among college roommates. Personality and Social Psychology Bulletin, 32(7), 907-916.

[7] Zimmerman, D. J. (2003). Peer effects in academic outcomes: Evidence from a natural experiment. Review of Economics and statistics, 85(1), 9-23.

[8] Jones, D. C., Vigfusdottir, T. H., \& Lee, Y. (2004). Body image and the appearance culture among adolescent girls and boys: An examination of friend conversations, peer criticism, appearance magazines, and the internalization of appearance ideals. Journal of adolescent research, 19(3), 323-339.

[9][10] Lessard, L. M., \& Juvonen, J. (2018). Losing and gaining friends: Does friendship instability compromise academic functioning in middle school?. Journal of school psychology, 69, 143-153.

[11] Arnett, J. J. (2000). Emerging adulthood: A theory of development from the late teens through the twenties. American psychologist, $55(5), 469$.
[12] McInnis C, James R \& Hartly R (2000) Trends in the first year experience; in Australian universities. Centre for the Study of Higher Education, the University of Melbourne.

[13] Braxton, J. M., Vesper, N., \& Hossler, D. (1995). Expectations for college and student persistence. Research in higher education, 36(5), 595-611.

[14] Tomé, G., de Matos, M. G., Simões, C., Camacho, I., \& AlvesDiniz, J. (2012). How can peer group influence the behavior of adolescents: explanatory model. Global journal of health science, 4(2), 26.

[15] Ueno, K. (2005). The effects of friendship networks on adolescent depressive symptoms. Social Science Research, 34(3), 484-510.

[16] Brown, B. B., \& Larson, J. (2009). Peer relationships in adolescence. Handbook of adolescent psychology, 2.

[17] Vaquera, E., \& Kao, G. (2008). Do you like me as much as I like you? Friendship reciprocity and its effects on school outcomes among adolescents. Social science research, 37(1), 55-72.

[18] Ruini, C., Ottolini, F., Tomba, E., Belaise, C., Albieri, E., Visani, D., ... \& Fava, G. A. (2009). School intervention for promoting psychological well-being in adolescence. Journal of behavior therapy and experimental psychiatry, 40(4), 522-532.

[19] Strayhorn, T. L. (2014). What role does grit play in the academic success of black male collegians at predominantly white institutions?. Journal of African American Studies, 18(1), 1-10.

[20] Pascarella, E. T., \& Terenzini, P. T. (2005). How College Affects Students: A Third Decade of Research. Volume 2. Jossey-Bass, An Imprint of Wiley. 10475 Crosspoint Blvd, Indianapolis, IN 46256.

[21] Blimling, G. (2010). The resident assistant: Applications and strategies for working with college students in residence halls. Dubuque, IA: Kendall Hunt. Blimling, G.(2015). Student learning in college residence halls: What works, what doesnt, and why.

[22] Liu, A., Sharkness, J., \& Pryor, J. H. (2008). Findings from the 2007 administration of your first college year (YFCY): National 
Aggregates. Los Angeles, CA: Higher Education Research, University of California, Los Angeles.

[23] American College Health Association. (2012). American College Health AssociationNational College Health Assessment Spring 2012 Reference Group Data Report (abridged): The American College Health Association. Journal of American college health: J of ACH, 57(5), 477.

[24] Trail, T. E., \& West, T. V. (2009). Interracial roommate relationships: Negotiating daily Interactions. Personality and Social Psychology Bulletin, 35(6), 671-684.

[25] West, T. V., Pearson, A. R., Dovidio, J. F., Shelton, J. N., \& Trail, T. E. (2009). Superordinate identity and intergroup roommate friendship development. Journal of Experimental Social Psychology, 45(6), 12661272. 